\title{
KONFLIK DAN RESOLUSINYA DALAM PERSPEKTIF ISLAM
}

\author{
Akhmad Rifa'i \\ Fak. Dakwah UIN Sunan Kalijaga Yogyakarta \\ Email: arifai_yk05@yahoo.com.sg
}

\section{Abstract}

Al-Quran as a source of Islamic law have been explained systematically, that the human condition will be conflict in the interaction between each other. In verse of al-Baqara (2:30), even before the creation explains Adam (first human), Angel says that man is only to conflict and corruption on the earth. Here is not inevitable, the Qur'an has so far explained the conflict before humans existed. Al-Quran itself explains also that the conflicts that exist in humans can be resolved. The Qur'an has a draft resolution. Explanation verse of An-Nisa (4:35) and a verse of al-Hujurat (49:09) provide evidence that Al-Quran is concerned with the conflict. Conflict resolution offered by the Qur'an when it conflicts with a person or party outside, Hakam must be able to reconcile the conflicting parties. Hakam or arbitrator in the science of conflict resolution is often called a mediator in the mediation system. Conflict and resolution in the perspective of Islam (the Qur'an), so badly needed in answering the question of existing conflicts in human life.

$$
\begin{aligned}
& \text { مستخلص } \\
& \text { آلقرآن كما كانت مصدرا للشريعة الإسلامية وأوضح بشكل منهجي ، أن الشرط الإنسان سيكون }
\end{aligned}
$$

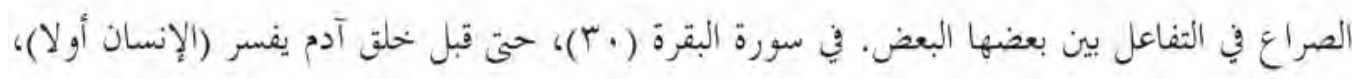

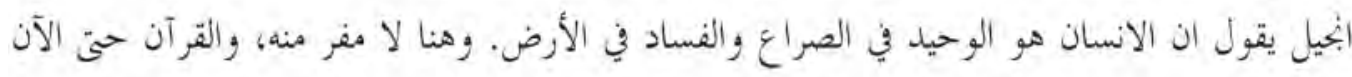

$$
\begin{aligned}
& \text { أوضح التراع قبل وجود الإنسان. آل القرآن نفسه يفسر أيضا أنه يمكن حل الصراعات التي توجد في } \\
& \text { البشر . القر آن يحتوي على مشروع القرار. الرسالة شرح سورة النساء (ب0) وسورة الحجرات (9) تقدم }
\end{aligned}
$$




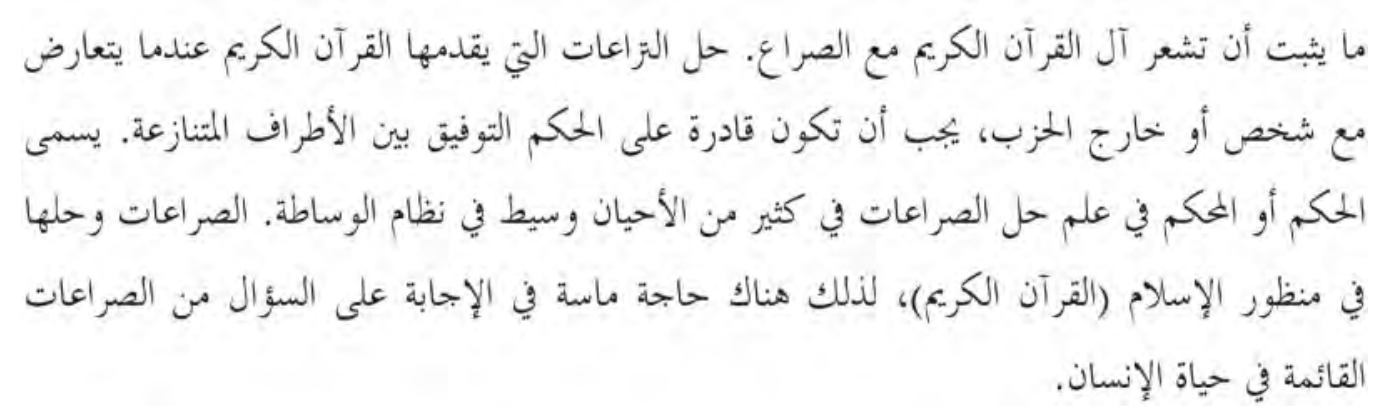

Keywords: Al-Quran, Konflik, Resolusi Konflik, dan Mediasi

\section{A. Pendahuluan}

Islam sebagai agama selalu mengajarkan kebaikan bagi umatnya, namun di sisi lain Islam juga menyebutkan ada keburukan yang harus diakui dalam kehidupan. Keburukan yang sering terjadi dan nampak dalam kehidupan ini dijelaskan dalam ajaran Islam dalam kitabnya yaitu Al-Quran. Kisah-kisah seperti perseteruan antara Habil dan Qobil yang saling berkelahi, Nabi Nuh dengan kaumnya, Nabi Ibrahim dengan Abrahah, Nabi Musa dengan Fir'aun, begitu pula antara kaum Muslim dan Qurais yang saling berperang dan menghina semasa Islam datang pertama kali, ini mencerminkan bahwa manusia hidup di dunia ini tidaklah selalu dalam keadaan baik melainkan keburukan pun selalu mengitarinya. Al-Quran juga memberikan informasi bahwa manusia sebelum diciptakan sudah syarat akan konflik.

"Dimana tatkala Allah akan menciptakan kholifahNya di muka bumi, para malaikat mengajukan keberatan, karena menurut prediksinya, manusia itu hanya akan membudayakan kerusakan, kejahatan dan pertumpahan darah saja di muka bumi”."

Ayat ini menunjukkan, bahwa budaya merusak, jahat dan melakukan pertumpahan darah yang digambarkan dalam Al-Quran tadi menampakkan sebuah peringatan bahwa manusia sebagai makhluk yang sarat akan konflik.

Konflik dan kehidupan adalah dua hal yang tidak bisa dipungkiri adanya. Adanya dua hal itu dalam kehidupan manusia sudah di garis bawahi oleh AlQuran, dan secara ilmu pengetahuan pembahasan konflik dalam segi keilmuan pun kini telah banyak dibahas demi memberikan arahan dan dorongan terciptanya kebaikan dalam interaksi antar manusia. Konflik sendiri secara etimologi berasal dari kata conflict, yang dari bahasa latinnya confligere yang berarti: "saling mengejutkan” atau konflik terjadi karena ada pihak-pihak yang 'saling mengejutkan' 
dengan kata lain kekerasan. ${ }^{2}$ Selain itu, kata 'konflik' juga memiliki beberapa definisi, a fight, a collision; a struggle, a contenst; opposition of interest, opinions or purposes; mental strife, agony' (suatu pertarungan, suatu benturan; suatu pergulatan; pertentangan kepentingan-kepentingan, opini-opini, atau tujuan-tujuan; pergulatan mental, penderitaan batin). ${ }^{3}$ Maka penegasan 'konflik' secara ilmu dan Al-Quran ini, tidak lain adalah menunjukkan bahwa konflik atau pertikaian, telah ada dan menjadi bagian yang melekat dalam kehidupannya.

Kehidupan manusia dari segala lingkup telah syarat akan konflik. Untuk itu ada baiknya kita melihat lebih jauh apa yang digarisbawahi Al-Quran dan bagaimana resolusi atau penyelesaian bisa dilakukan. Ini agar manusia sebagai aktor kehidupan mampu mengurai dan memberikan kontribusi yang positif terhadap konflik. Kontribusi yang positif terhadap kajian konflik ini, melalui tulisan ini secara khusus akan difokuskan pada penguraian makna konflik dalam Al-Quran, kemudian bagaimana resolusinya. Agar uraian lebih dalam, persoalan Agama dalam situasi konflik dan Agama dan Resolusi konflik akan dibahas lebih awal.

\section{B. Agama dalam Situasi Konflik}

Dalam menyebarluaskan cita-cita dan nilai-nilai yang dijunjung tinggi oleh kelompok dan individu, agama sangat mempengaruhi tujuan perilaku seseorang dalam situasi konflik. Seseorang lalu menetapkan kriteria atau kerangka acuan untuk menentukan benar dan salahnya suatu (penyebab) peristiwa. Dilihat dari perspektif agama, konflik tidak hanya ditafsirkan sebagai hancurnya hubungan horizontal sesama manusia, tetapi juga sebagai hancurnya hubungan vertikal dengan sang Ilahi.

Dalam 'kesemestaan budaya kultural bersama' atau 'kosmologi kolektif' dimana agama melengkapi beroperasinya tingkat kesadaran dan ketidak sadaran bertindak seseorang. Kedua tingkat kesadaran itu ikut bermain di tengah-tengah konflik. Dalam perselisihan, yang menyertai konflik bisa mengganggu dan menggoyang aturan yang tak tertulis, harapan yang diinginkan dan memperkuat kecenderungan untuk membingkai hubungan dalam kategori keagamaan. Dalam konteks ini, prasangka religius tentang 'diri', 'yang lain', 'konflik' dan 'damai' muncul, sebagai individu

2 Johan Galtung, "Mencari Solusi yang Ampuh bagi Konflik" dalam Dewi Fortuna Anwar., dkk (eds), Konflik Kekerasan Internal (Jakarta: Yayasan Obor Indonesia, 2005), hal 396.

3 Hoda Lacey, How to Resolve Conflict in the Workplace (terj) Bern. Hidayat (Jakarta, Gramedia Pustaka Utama: 2003), hal 17-18. 
atau kelompok ikut membingkai konflik, memberi makna dan tanggapan yang sesuai dengan nilai-nilai dan tujuan resolusi. ${ }^{4}$

Dengan mengakui penampilan bagai seorang model atau preseden perilaku yang diinginkan dalam situasi konflik, dan secara khusus mengingatkan orang lain, agama secara implisit mempengaruhi keinginan dan kemungkinan program tindakan tertentu dari orang lain. Ketika ini digunakan secara konstruktif, agama dapat mempengaruhi respon individu dan sosial untuk memicu peristiwa melalui: ${ }^{5}$ menempatkan peristiwa itu dalam konteks historis, konteks mencari tujuan, memberikan makna bagi peristiwa dengan nilai-nilai yang jelas, tujuan dan identitas agama dan menawarkan peran untuk menangani konflik secara tepat, respon afirmatif berdasarkan ajaran agama dan model-model ideal. Ketika dihadapkan dengan tantangan yang sulit atau ketidakpastian dalam konflik, mereka akan berpegang pada kode etik yang diyakini untuk mengurangi disonansi kognitif, kecemasan dan rasa bersalah serta memperlihatkan jalur kebenaran (berdasarkan program ideal dari tindakan) yang menjanjikan pengembalian harmoni dan ketertiban .

\section{Agama dan Resolusi Konflik}

Sangat penting untuk mengakui bahwa pengalaman konflik membangkitkan perenungan mendalam sebagai penegasan identitas dan perbaikan makna. Resolusi konflik tidak lebih dari benturan kepentingan materi; ia membicarakan reintegrasi, pemulihan dan penebusan dosa sosial, keamanan eksistensi, transendensi dan transformasi pribadi. Konsep-konsep ini diambil dari latar belakang dari yang suci, yang dapat didefinisikan sebagai suatu proses yang secara eksplisit menghubungkan kita dengan konteks yang mungkin lebih besar dari milik kita. ${ }^{6}$ Penegasan identitas individu dan kelompok dicapai melalui transformasi esensial di dalam memberikan makna sebuah konflik dan resolusi. Upaya perpecahan spiritual dari praktek-praktek penyelesaian konflik menolak komponen penting pengampunan dan pemulihan

4 Said, Abdul Aziz, Nathan C. Funk and Ayse S. Kadayifci, eds. Peace and Conflict Resolution in Islam: Precept and Practice. (Lanham: University Press of America, 2001), hal 67.

5 Ibid.

6 Said, Abdul Aziz, Charles O. Lerche, Jr. and Charles O. Lerch, III. Concepts of International Politics in Global Perspective, 4th edn. (Englewood Cliffs: Prentice Hall, Inc., 1995) hal. 120; Bateson, Gregory and Mary Catherine Bateson. Angels Fear: Towards an Epistemology of the Sacred. (New York: Bantam Books, 1987), hal. 77. 
dosa sosial yang memungkinkan konflik harus bisa diselesaikan.

Kosmologi agama kelompok, dalam mengistimewakan beberapa nilai dan citacita atas orang lain, menentukan bagaimana restorasi, keutuhan dan pengampunan dapat dicapai melalui jalur khusus yakni resolusi dengan mengadopsi bagian-bagian budaya yang berbeda. ${ }^{7}$ Pendekatan resolusi konflik yang tidak memasukkan bagian budaya yang sesuai dan relevan untuk transformasi pengampunan, lebih kecil kemungkinannya bisa menghasilkan resolusi yang kekal atau efektif. Perpecahan yang dialami dalam situasi konflik sering membutuhkan pertukaran simbol sosial atau yang lain yang ada dalam kosmologi kolektif. Dengan cara ini, strategi resolusi konflik mengajukan konsep khas perdamaian, yang menerangi syarat dan kondisi yang diperlukan untuk harmoni sosial yang bisa dipahami dan dirasakan.

Sebagai contoh, dalam resolusi konflik pada kosmologi Kristen dan beberapa pendekatan Barat, tanggapan pribadi seperti sebuah aspirasi terhadap yang kuasa atau dorongan keinginan transformasi, yang tidak menekankan pada sejarah masa lalu yang memungkinkan pembaharuan dan revisionisme. Ini sejalan dengan penekanan tradisi Kristen dalam hubungan pribadi, sang Ilahi dan nilai sosial yang diidamkan melekat dalam pencapaian kepentingan individu. ${ }^{8}$ Secara signifikan, tradisi Kristen berbeda dengan tradisi-tradisi monoteis lain yang mendorong secara komprehensif pendekatan resolusi konflik sepihak, sedangkan dalam Islam dan Yahudi, timbal balik atau tindakan sosial menandakan tercapainya resolusi dalam konteks historis yang lebih besar. Peran masyarakat dan tokoh masyarakat dalam mencapai solusi yang bisa diterima secara historis dan komunal merupakan bukti tersendiri pendekatan Islam dalam resolusi konflik.

\section{Konflik dalam Perspektif Islam}

Islam (Al-Quran) menginformasikan secara sistematis kepada manusia, bahwa konflik atau pertikaian, telah ada dan menjadi ketentuan dalam kehidupannya. Manusia digambarkan dalam Al-Quran selalu melakukan pertikaian, baik pertikaian antar personal, keluarga, dan sosial. Al-Quran menggambarkan konflik sosial dalam dua bentuk, yaitu bentuk potensial dan bentuk aktual. Konflik dalam bentuk

7 Abu-Nimer, Mohammad. "Conflict Resolution in an Islamic Context: Some Conceptual Questions”, dalam Peace \& Change. Vol. 21, No. 1. (January 1996), hal. 23.

8 Tarnas, Richard. The Passion of the Western Mind. (New York: Ballantine Books, 1991), hal. 40 . 
potensial disebutkan Al-Quran dengan menggunakan kata “” (permusuhan), sedangkan konflik aktual digambarkan dengan menggunakan kata "” (perselisihan/ pertengkaran) dan “" (pembunuhan). ${ }^{9}$

\section{Konflik Potensial}

Kata "” dan beberapa kata bentukannya menggambarkan potensi konflik dalam diri manusia. Dari hasil analisis terhadap beberapa ayat Al-Quran, ditemukan bahwa secara umum potensi konflik dapat dibagi pada potensi konflik universal. Potensi konflik universal ialah potensi berselisih yang dimiliki setiap individu dalam berinteraksi. ${ }^{10}$ Potensi konflik seperti ini dimiliki oleh setiap manusia, sekalipun tidak saling mengenal antara satu dengan lainnya. Potensi seperti ini dapat dirasakan ketika bertemu dengan orang untuk pertama kalinya dalam sebuah perjamuan malam, misalnya, akan tetapi karena satu hal yang tidak kita sukai, baik prilaku, tutur kata, maupun warna dan busana yang dipakainya, kita dapat saja mempunyai kesan tidak senang padanya. Jelasnya, potensi konflik universal tidak membutuhkan adanya interaksi atau kontak sosial sebelumnya, sebab potensi ini melekat dalam diri setiap individu. ${ }^{11}$

Potensi konflik universal dapat berbentuk konflik intrapersonal dan interpersonal. Konflik intrapersonal adalah potensi konflik yang muncul dalam "diri" setiap orang, yakni potensi perselisihan antara dorongan-dorongan kebaikan ${ }^{12}$ dan keburukan..$^{13}$ Dorongan untuk melawan atau menyatakan permusuhan terhadap kebaikan ditunjukkan dengan adanya dorongan berbuat kejahatan dan keburukan. Sebaliknya, adanya kesadaran melawan dorongan kejahatan ditunjukkan dengan kuatnya dorongan berbuat kebaikan. ${ }^{14}$ Konflik intrapersonal ini sering dialami ketika kita menghadapi pilihan untuk melakukan atau menolak mengerjakan sesuatu. Dalam kondisi seperti ini, kita dapat saja menyalahkan dan membenci, bahkan menyakiti dan membunuh diri sendiri.

9 M.F. Zenrif., Realitas \& Metode Penelitian Sosial dalam Perspektif Al-Quran (Malang: UIN Malang Press, 2006), hal 50-51

10 Perhatikan al-Baqarah (2:36); al-A'raf (7: 24); dan Thaha (20: 123).

11 M.F. Zenrif., op.cit, hal 51

12 Hal ini digambarkan sebagai sebuah potensi "ketuhanan" dan "kemalaikatan" yang muncul dalam setiap pribadi manusia mukmin. Potensi ini ditunjukan dalam ayat al-Baqarah (2:97); dan al-Baqarah (2: 98).

13 Halaman ini digambarkan sebagai potensi "kesyetanan". Potensi ini ditunjukkan dalam ayat al-Baqarah (2:168); dan al-Baqarah (2: 208).

14 Perhatikan ayat al-Isra' (17:53). 
Konflik interpersonal ialah potensi yang ada dalam "diri” setiap orang untuk membenci dan memusuhi yang lain. Konflik ini dapat berbentuk individu-individu, ${ }^{15}$ antarindividu dalam keluarga, ${ }^{16}$ antarindividu yang terjalin dengan komitmen persahabatan, ${ }^{17}$ antaretnis atau komunitas masyarakat yang diikat dengan komitmen, baik komitmen kebangsaan atau kenegaraan, ${ }^{18}$ maupun komitmen keagamaan. ${ }^{19}$ Potensi konflik yang disadarkan atas komitmen keagamaan, di samping disebabkan permasalahan politik dan ekonomi, banyak didorong oleh penilaian yang negatif, yang berakhir dengan pengejekkan pada agama lain. ${ }^{20}$

Dilihat dari pandangan strukturalis, ada potensi konflik antara pimpinan, raja, presiden, rektor, atau direktur pada satu sisi, dan rakyat, mahasiswa, atau buruh pada sisi yang berlawanan. ${ }^{21}$ Potensi "konflik struktural" ini merupakan akibat dari ketidakadilan, kedhaliman, dan bentuk lain dari penindasan kaum elit terhadap masyarakat alit (kecil). ${ }^{22}$ Dalam pandangan struktur agama, potensi konflik dapat terjadi antara nabi, kyai, pendeta, pastur, biksu atau missionaris (da'i), dengan umatnya. ${ }^{23}$

Potensi konflik yang terakhir ini disebabkan ada sebagian masyarakat yang bersifat munafik dan menjadi demagog (penghasut), yakni seseorang yang mampu mempengaruhi kebanyakan masyarakat dan pimpinan dengan keindahan bahasa dan rasionalisasi analitis terhadap sebuah realitas. Sekalipun analisis para demagog tidak berdasarkan realitas yang sebenarnya, para demagog tetap mampu merasionalisasi informasinya sehingga seakan-akan apa yang diinformasikannya benar-benar berangkat dari sebuah realitas. ${ }^{24}$ Tindakan yang berangkat dari hasil analisis para demagog telah mengakibatkan kaum elit mengambil kebijakan yang kurang tepat, sebaliknya sebagian masyarakat memberikan penilaian terhadap pimpinan dengan salah disebabkan informasi yang tidak benar dari demagog.

15 Potensi konflik antarindividu ini digambarkan ayat al-Qashash(28): 19.

16 Keluarga yang dimaksudkan, baik bentukan keluarga yang didasarkan atas pertalian keturunan, seperti yang ditunjukkan ayat al-Taghabun (64:14), maupun keluarga yang didasrkan atas pertalian adopsi, seperti yang ditunjukkan ayat al-Qashash (28:8); dan al-Taubah (9:114).

17 Bacalah runtutan ayat yang berakhir dengan ayat al-Zukhruf (43:67).

18 Perhatikan ayat al-Nisa' (4: 92) dan al-Qashash (28: 15).

19 Perhatikan ayat al-Nisa' (4:101), al-Anfal (8: 60), al-Taubah (9: 83), al-Mumtahanah (60:1).

20 Periksa rentetan ayat dalam al-An'am (6:108).

21 Perhatikan surat Thaha (20: 80).

22 Yunus (19: 90).

23 Al-An'am (6: 112), al-Taubah (9: 120), dan al-Furqan (25: 31).

24 Al-Munafiqun (63: 4). 


\section{Konflik Aktual}

Konflik potensial yang disebut di atas, apabila diorganisir dan dimobilisasi massa, maka ia akan menjadi konflik aktual, yakni realitas konflik sosial. Dalam hal ini al-Quran menggambarkan konflik model ini dengan mengunakan kata “", pada tingkat konflik yang paling rendah, dan kata "'” untuk tingkat konflik yang tinggi.

Konflik sosial yang terendah ditunjukkan dalam berbagai model konflik; Pertama, dengan hadirnya demagog yang memberikan rasionalisasi yang menakjubkan tentang keberhasilan kehidupannya dan ditampakkan di depan orang banyak atas nama Tuhan, walaupun sesungguhnya yang berada di dalam jiwanya adalah kebalikan dari apa yang ada pada permukaannya. Salah satu ciri dari perilaku konflik yang disebabkan perbuatan demagog ialah; (a) sesuatu yang ada dalam hatinya jauh dari kenyataan yang ditampakkannya di depan orang banyak, (b) Apabila dia berada di belakan orang banyak, dia justru membuat kerusakan di atas bumi; (c) Apabila diingatkan, dia menunjukkan kesombongan dan keangkuhan. ${ }^{25}$

Kedua, konflik sosial yang didahului oleh perdebatan (mujadalah), ${ }^{26}$ yaitu perdebatan antara logika yang benar dan yang salah, kebaikan dengan keburukan, dan antara keadilan dengan kebatilan. Konflik seperti ini sering terjadi antara mereka yang mengajak kepada kebenaran dan mereka yang mempertahankan tradisi yang salah. ${ }^{27}$

Ketiga, konflik keluarga disebabkan permasalahan kekeluargaan, seperti pengasuhan anak, pemilikan terhadap harta waris, kecemburuan terhadap pasangannya, dan segala bentuk konflik keluarga. ${ }^{28}$ Konflik seperti ini banyak terjadi di Negara-negara maju maupun berkembang yang fenomenanya dapat dilihat dari meningkatnya angka perceraian dan gugat cerai.

Keempat, "perang dingin” antarumat beragama, yaitu konflik antarumat beragama, kelompok mukmin pada satu sisi dan kelompok kafir pada sisi lain. ${ }^{29}$

25 Al-Baqarah (2: 204-206).

${ }^{26}$ Mujadalah (debat) dan beberapa kata jadiannya disebutkan al-Quran sebanyak 29 kali, dalam surat al-Baqarah (2: 197), al_nisa'(4:107, 109), al-An'am (6: 25), al-A'raf (7: 71), al-Anfal (8:6), Hud (11:32, 74), al-Ra'd (13: 13), al-Nahl (16: 111, 125), al-Kahfi (18: 54, 56), al-Hajj (22: 3,8, dan 68), al-Ankabut (29: 46), Luqman (31:20), al-Mukmin (40: 4,5,35,56, dan 69), al-Syu'ara (42: 35), alZukhruf (43: 58), dan al-Mujadilah (58: 1).

27 Al-Zukhruf (43: 58)

28 Ali-Imran (3: 44).

29 Al- Naml (27: 45), dan al-Hajj (22: 19). 
Konflik seperti ini ialah konflik yang terselubung dalam setiap perdebatan dan kajian keagamaan. Secara akademik, kita melihat konflik ini dalam berbagai literatur tentang kajian keagamaan, dimana masing-masing pengkaji menyatakan yang paling objektif dan akhirnya membenarkan agamanya masing-masing.

Kelima, konflik antara orang yang melakukan perserikatan dan kerjasama dengan tidak menggunakan manajemen yang baik. ${ }^{30}$ Sistim kerjasama atau perserikatan ini dapat terjadi dalam skala personal, komunitas sosial yang diwakili oleh organisasi institusional (antarlembaga), regional (antarpropinsi), nasional (antarnegara) maupun internasional (antara Negara-negara yang berkelompok dalam suatu badan atau organisasi). Setiap hubungan kerjasama atau perserikatan yang dilakukan dengan cara tidak professional dan terbuka, merupakan bentuk dari konflik sosial yang apabila terakumulasi akan menjadi ledakan konflik yang membahayakan hubungan tersebut.

Keenam, konflik sosial diakibatkan perbedaan pandangan tentang kekayaan dan konservasi alam, perbedaan pandangan ini berakibat pada upaya untuk mempertahankan pandangan yang karena ketidaktahuannya mengakibatkan pada kesalahan, namun dengan kesombongannya kemudian berwujud dalam bentuk makar. ${ }^{31}$ Makar ini ditunjukkan dengan cara mengeksploitasi alam untuk menunjukkan kebenaran dan kemenangannya sehingga mengakibatkan kerusakan eko sistem dan makro kosmik. Pada dunia kita sekarang, kita melihat bagaimana barat (Negaranegara industri) telah menghabiskan seluruh kekayaan alamnya untuk dieksploitasi demi kepentingan industrialisasi, namun pada sisi lain Barat meminta agar negaranegara tertinggal di Timur melakukan konservasi alam demi keutuhan eko sistem dan makro kosmik. Konflik seperti ini sering tampak kepermukaan dalam bentuk "perang dingin” antara Barat (Negara kaya) dan Timur (Negara miskin).

Ketujuh, bentuk konflik sosial diakibatkan terjadinya pencurian, korupsi, manipulasi, pengurangan timbangan atau ukuran, dan beberapa bentuk pengambilan hak orang lain dengan tidak sah. ${ }^{32}$ Korupsi dan manipulasi yang terjadi di beberapa Negara berkembang, khususnya Indonesia, telah mengakibatkan terjadinya konflik sosial, baik vertikal maupun horisontal. Terjadinya demonstrasi di berbagai daerah sebagai bentuk respon terhadap terjadinya korupsi dan manipulasi adalah salah

30 Shad (38: 21-24). Ayat ini secara lugas menceritakan terjadinya konflik diakibatkan sistem manajemen yang tidak baik dalam melakukan perserikatan.

31 Al-Nahl (16: 3-26)

32 Al-Nisa' (4: 105), sekalipun ayat ini menggambarkan kondisi ketika masa Rasulullah saw, akan tetapi ayat ini juga menggambarkan telah terjadinya konflik yang diakibatkan pencurian. 
satu indikasi yang menunjukkan terjadinya konflik bentuk ini.

Sementara itu, kata “" yang menunjukkan pada tingkatan konflik aktual yang tinggi dapat terjadi antarpersonal yang diakibatkan permasalahan keluarga, baik karena permasalahan perkawinan yang tidak disetujui maupun disebabkan masalah warisan, ${ }^{33}$ antar etnis dan agama yang disebabkan fitnah, ${ }^{34}$ antarnegara (pemerintahan), ${ }^{35}$ atau peperangan antaragama (perang suci) ${ }^{36}$ Bentuk-bentuk konflik ini hingga kini dapat kita amati dengan jelas dalam berbagai kehidupan sosial, sekalipun dengan motif dan dorongan yang berbeda dengan apa yang ada dalam setiap ayat secara tekstual.

Fenomena konflik sosial ini dapat dilihat dari terjadinya pembunuhan yang tidak disengaja atau melakukan sesuatu dengan tidak bermaksud untuk membunuh, akan tetapi secara tidak langsung mengakibatkan terjadinya pembunuhan, ${ }^{37}$ atau pembunuhan terhadap individu atau perusakan terhadap alam semesta, ${ }^{38}$ pembunuhan terhadap pimpinan (Negara maupun agama), ${ }^{39}$ atau pembunuhan terhadap anak sendiri. ${ }^{40}$

Konflik potensial dan aktual yang telah dijelaskan dalam Al-Quran tidak lain agar kita mengetahui potensi-potensi dan gambaran konflik yang sering terjadi dalam kehidupan antar manusia. Selain kita mengetahui sejauhmana keberadan konflik yang ada dalam hidup, Al-Quran juga memberikan resolusi disetiap konflik yang ada didalamnya. Karena bagi penulis, konflik sendiri bagaikan 'penyakit' yang harus ada 'obatnya'.

\section{E. Resolusi Konflik dalam Perspektif Islam}

Resolusi konflik harus dipahami sebagai suatu penyelesaian dimana pihak diluar pihak-pihak yang berkonflik dapat membantu dan mengarahkan konflik yang negatif

33 Al-Maidah (3: 30).

34 Al-Baqarah $(2: 191,217)$

35 Al-Baqarah (2: 251)

36 Muhammad (47: 4).

37 Al-Nisa' (4: 92).

38 Al-Maidah (5: 32).

39 Al-Quran menggambarkan kebiasaan masyarakat yang membunuh para Nabi, seperti digambarkan Al-Imran (3: 181 dan 183), al-Nisa' (4: 155); lihat juga Abu Abdullah. Muhammad ibn Ahmad al-Anshar; al-Qurthubi. Al-Jami li-Ahkam al-Qur'an. Vol. 14. (Kairo Dar al-Katib al Arabi li al-Thibaah wa al-Maaya, 1987).

40 Al-An'am (7: 137 dan 140) 
menjadi konflik yang positif. Hal ini sangat penting terkadang pihak-pihak diluar yang berkonflik bukan membantu memecahkan konflik justru menjadi a part of problem. Apalagi konflik keagamaan, terkadang norma agama pun mereka abaikan, seperti halnya jika yang berkonflik adalah pihak-pihak yang mengatasnamakan agama, pasti pihak lainnya ingin membantu lantaran mereka seagama dan dengan emosi yang lebih ditonjolkan, bukan akal sehat atau normanya yang berjalan. Selain itu, istilah "pencegahan konflik" mengungkapkan penekanan yang diberikan oleh pengelakkan terhadap pergolakan, sebagai perlawanan terhadap aktivitas untuk mempertentangkan dan mencegah segala bentuk kekerasan dan menanggulangi eksploitasi, diskriminasi, pengusiran, serta penindasan. Oleh karena itu, dengan sedikit keadilan, resolusi konflik dipandang sebagai alat dari sebuah pengamanan-sebagai senjata baru yang lebih kokoh dalam kekuatan mereka yang diuntungkan oleh status quo, daripada sebuah sarana demi mencapai perdamaian yang disertai dengan keadilan. Maka peran dari 'pihak ketiga' adalah membantu pihak-pihak yang terlibat konflik untuk mencari jalan keluar yang saling menguntungkan. ${ }^{41}$

Dalam sebuah konflik mungkin ada beberapa alasan kedua pihak yang terlibat tidak cukup mampu untuk keluar dari apa yang mereka perselisihkan, karena mereka tidak cukup rasional, oleh karenanya membutuhkan pihak diluarnya. Pihak luar atau pihak ketiga kehadirannya sangat dibutuhkan untuk menyelesaikan konflik agar konflik dapat dikelola dan dihindari dari tindak diskriminasi, kekerasan, dan lainnya. Sebagaimana Al-Quran menegaskan untuk menghadirkan pihak ketiga, "Dan jika kamu khawatir terjadi persengketaan antara keduanya, maka kirimlah seorang juru damai dari keluarga laki-laki dan seorang juru damai dari keluarga perempuan. Jika keduanya (juru damai itu) bermaksud mengadakan perbaikkan, niscaya Allah memberikan taufik kepada suami-istri itu. Sungguh Allah Maha Mengetahui, Mahateliti. "\$2 Penekanan dari saya, Juru damai adalah pihak ketiga atau orang yang tidak terlibat dalam pertikaian dan memiliki tujuan untuk mendamaikan. Bukan hanya dalam konflik keluarga, tapi Al-Quran juga menegaskan agar penggunaan pihak ketiga diterapkan dalam konflik sosial, "Dan apabila ada dua golongan orang mukmin berperang, maka damaikanlah antar keduanya. Jika salah satu dari keduanya berbuat zalim terhadap (golongan) yang lain, maka perangilah perangilah (golongan) yang berbuat zalim itu, sehingga golongan itu hal. 56-57

${ }^{41}$ Diana Francis, Teori Dasar Transformasi Konflik Sosial, (Yogyakarta: Penerbit Quills, 2006),

${ }^{42}$ An-Nisaa (4: 35) 
kembali kepada perintah Allah. Jika golongan itu telah kembali (kepada perintah Allah), maka damaikanlah antara keduanya dengan adil, dan berlakulah adil. Sungguh, Allah mencintai orang-orang yang berlaku adil." ${ }^{\text {33 }}$ Ayat ini, memberikan penjelasan pada pihak ketiga, apabila melihat pertikaian wajib memberikan penengahan untuk mewujudkan perdamaian diantara mereka.

Dalam perkembangan ilmu resolusi konflik pihak ketiga yang memberikan perdamaian atau penengahan diantara pihak yang berkonflik sering disebut dengan sistem mediasi dan Al-Quran sering mengkiaskan dengan kata hakam. Mediasi atau hakam dalam setiap terjadinya konflik keberadaanya sering dibutuhkan agar perdamaian dapat terwujud. Semangat Al-Quran yang telah memberikan obat bagi 'konflik' sangatlah relevan di jaman modern melihat setiap orang yang terlibat konflik mengharapkan penyelesaian yang adil (win-win solution), dan keadilan itu di dapat bukan dari mereka yang berkonflik tapi butuh kekuatan diluar mereka yang mampu menjadi hakam atau mediator. Selanjutnya, mediasi sebagai resolusi konflik akan dijelaskan sebagai berikut:

\section{F. Mediasi Sebagai Resolusi Konflik}

Perlu di pahami bahwa sistem mediasi dalam resolusi konflik menuntut perubahan bukan hanya dari luar melainkan juga dari dalam. Perubahan yang merupakan hasil pemaksaan kehendak belaka bukanlah resolusi, melainkan sekadar menyesuaikan diri terhadap tekanan dari kekuatan yang lebih dahsyat. Perubahan yang dipaksakan memang bisa membuka kesempatan bagi berlangsungnya jenis perjumpaan reflektif yang dituntut dalam resolusi, namun tanpa perjumpaan semacam itu maka pemaksaan kehendak hanya akan menimbulkan polarisasi dan memecah-belah tanpa menghasilkan perubahan sejati. Segera sesudah pemaksaan tersebut dihentikan, maka segalanya akan kembali seperti sedia kala, yaitu maraknya pola-pola destruktif yang semakin mengerikan. ${ }^{44}$

Resolusi konflik memiliki serangkaian tuntunan yang bersifat paradoksal terhadap mereka yang menunjukkan komitmen untuk memfasilitasikan. Pada satu sisi, proses mediasi menuntut komitmen yang jelas dan teguh untuk menolong orang lain tumbuh dan berubah dalam rangka mencapai perkembangan potensi diri sepenuh-penuhnya serta menghormati potensi itu dalam diri mereka. Pada sisi lain, proses mediasi menuntut pengelolaan diri secara cermat agar mampu

\footnotetext{
43 Al-Hujurat (35: 09)

${ }^{44}$ Ronal. S. Kraybill., Op.cit, hal. 29
} 
mempertahankan sikap fasilitatif dan persuatif, yang mutlak diperlukan bagi kemungkinan terjadinya resolusi.

Orang-orang semacam itu disebut sebagai para juru damai. Mereka mengakui bahwa perdamaian hanya bisa dibangun secara pelan-pelan lewat serangkaian proses perjumpaan dan refleksi bukan hanya tentang perkara-perkara praktis yang biasa muncul dalam sebuah konflik, melainkan juga tentang persoalan-persoalan yang lebih mendalam seperti soal relasi, perkembangan manusia, dan berbagai realitas struktural.

Bagi mereka, konflik bukan sekedar percikan-percikan friksi antara dua seteru yang mustahil diubah, melainkan sebuah kobaran api yang mampu mentransformasikan orang untuk menghasilkan panas. Mereka berupaya hadir dalam jangka waktu panjang agar dapat menolong mengendalikan energi konflik serta mengarahkan secara positif untuk mengubah dan membarui masyarakat umat manusia. ${ }^{45}$

Kalau perhatian para juru damai hanya diarahkan untuk mengakhiri konflik, maka kehadiran mereka justru akan lebih banyak membawa kerugian daripada kebaikan. Sebagai contoh, jika sekelompok juru damai berhasil mencapai "perdamaian" tanpa mengupayakan agar pihak-pihak yang bertikai menyelesaikan akar-sebab dari konflik mereka serta peran mereka sendiri dalam mempertahankan sebab-sebab tersebut, berarti mereka hanya mengulur-ulur waktu sebelum akhirnya perkara-perkara yang sangat penting itu diselesaikan. Jika orang dihalangi kebutuhannya untuk mengungkapkan berbagai pandangan serta ketidaksetujuan mereka, maka kebencian dan frustasi pun akan merebak dan semakin destruktif. Biasanya tidak berapa lama sesudahnya emosi-emosi negatif tersebut akan meledak. Maka yang perlu segera dilakukan adalah menciptakan berbagai saluran dan struktur sehingga pihak-pihak yang berseteru dapat mengungkapkan aneka keprihatinan dan perasaan mereka dengan cara-cara yang semestinya. Bila terjadi ketimpangan kekuasaan yang berarti, tantangan menentukan yang harus ditempuh oleh juru damai adalah mengupayakan agar pihak yang lebih lemah bisa mengungkapkan keprihatinan mereka tanpa secara konyol justru menempatkan mereka dalam bahaya. Kadang-kadang upaya juru damai tersebut justru menjadikan konfliknya sendiri tanpa memanas, sebab salah satu hasil yang lazim dicapai adalah meningkatkan ungkapan aneka pandangan yang saling betentangan. Namun, sepanjang orang-orang tersebut tahu bahwa mereka akan diberi kesempatan untuk menyuarakan keprihatinan mereka, sering kali cara mereka saling berinteraksi menjadi semakin konstruktif. ${ }^{46}$

45 Ibid, hal. 30

46 Ibid, hal. 31 
Pihak ketiga atau juru damai bekerja dengan cara-cara yang menyumbang bagi perkembangan pribadi orang-orang yang terlibat dalam konflik. Sepanjang manual ini, para juru damai diingatkan agar menjalin relasi dengan pihak-pihak yang bertikai dengan cara-cara yang bertujuan meningkatkan kemampuan masing-masing pihak mempertimbangkan pilihan-pilihan mereka dengan matang, dan mengambil peran aktif dalam membuat keputusan-keputusan serta tidak menyerahkannya ke tangan orang lain. Jika para juru damai sungguh-sungguh mampu memperdayakan orang lain dengan cara ini, berarti mereka telah memberikan sumbangan bagi tegaknya keadilan, sebab mereka membekali orang-orang dengan kemampuan agar bisa ikut ambil bagian dalam mengupayakan kemerdekaan mereka sendiri dari aneka situasi dan struktur yang menindas dan melecehkan martabat kemanusiaan mereka. ${ }^{47}$ Oleh karena itu, peran pihak ketiga atau mediator sangat memberikan kontribusi terwujudnya keadilan diantara pihak-pihak yang bertikai atau berkonflik.

Mediasi merupakan sarana yang dapat memperdayakan semua orang untuk memecahkan berbagai konflik mereka sendiri serta bertanggung jawab atas kehidupan mereka. Namun, kiranya terlebih dahulu perlu dipahami apa yang boleh dan tidak boleh dilakukan oleh seorang mediator agar pemberdayaan yang dimaksud sungguhsungguh berjalan. Sebagai contoh: ${ }^{48}$

1. Mediator tidak boleh membuat keputusan-keputusan bagi orang-orang yang didampinginya atau mendikte apa yang harus mereka kerjakan.

2. Mediator tidak boleh berusaha menghimpun kekuasaan atas kehidupan orangorang yang didampinginya.

3. Mediator tidak memiliki jawaban bagi aneka persoalan yang dihadapi oleh orang-orang yang didampinginya.

4. Mediator tidak bertanggung jawab bila proses mediasi gagal; (dengan asumsi bahwa mereka telah melaksanakan tugas mediasi tersebut dengan baik dan benar).

5. Mediator tidak boleh merasa berjasa bila proses mediasi berhasil (sekalipun mereka telah melaksanakan tugas mediasi tersebut dengan sangat baik).

Sifat konflik adalah sunnatullah, karena itu diperlukan penyelesaian secara tidak memaksa dengan sistem mediasi. Memberikan pemahaman bahwa konflik ada dan harus diselesaiakan secara bijak, dengan mengembalikan semua konflik kepada mereka

47 Ibid, hal. 31; Al-Zastrouw. Reformasi Pemikiran (Respon Kontemplatif Terhadap Persoalan Kehidupan dan Budaya), (Jakarta: LKPSM, 1998), hal. 24.

48 Ibid., hal. 53; lihat pula Ahmad Musthafa al-Maraghi. Terjemah Tafsir al-Qur'an, (Semarang: Toha Putra, 1992). 
yang terlibat didalamnya tanpa harus mediator/hakam bagian dari konflik, namun justru mediator/hakam mampu menjadi fasilitator demi terwujudnya perdamaian.

\section{G. Penutup}

Konflik adalah bagian dari kehidupan manusia, dimana keberadaan-nya secara sistematis telah banyak digambarkan dalam Al-Quran, oleh karenanya 'konflik' bukanlah sesuatu yang harus dihindari dalam kehidupan manusia. Namun, Islam (Al-Quran) pun tidak sekedar memberikan gambaran konflik secara sistematis tapi Al-Quran dalam konteks kitab pun memiliki resolusi atas konflik yang ada.

Resolusi konflik dalam perspektif Islam adalah sebuah jalan baru yang memberikan kontribusi terhadap 'konflik' dengan memperhatikan ilmu pengetahuan yang berkembang saat ini, konsep hakam dalam Al-Quran tidak lain justru sebagai progress dalam perkembangan pemikiran Islam, dimana setiap terjadi konflik dibutuhkan seorang hakam atau juru damai yang mampu menciptakan suasana konflik menjadi damai. Dengan adanya semangat hakam dalam perspektif Al-Quran ini, justru menguatkan sistem mediasi yang berkembang dalam ilmu resolusi konflik, karena hanya dengan sistem mediasi seorang juru damai mampu mengambil sikap netral dan hanya memiliki satu tujuan, yaitu mendamaikan pihak-pihak yang berkonflik.

\section{DAFTAR PUSTAKA}

Abu Abdullah. Muhammad ibn Ahmad al-Anshar; al-Qurthubi, 1987. Al-Jami 1iAhkam al-Qur'an. Vol. 14. Kairo Dar al-Katib al Arabi li al-Thibaah wa alMaaya.

Abu-Nimer, Mohammad. 1996. "Conflict Resolution in an Islamic Context: Some Conceptual Questions”, dalam Peace \& Change. Vol. 21, No. 1. January, hal. 22-40.

Ahmad Musthafa al-Maraghi, 1992. Terjemah Tafsir al-Qur’an, Semarang: Toha Putra. Al-Zastrouw, 1998. Reformasi Pemikiran (Respon Kontemplatif Terhadap Persoalan Kehidupan dan Budaya), Jakarta: LKPSM.

Asep Sabar Aputra, 2000, Dekonstruksi Paradigma Kritis Komunitas Tradisional, Jakarta: Bumi Selamat.

Asghar Ali Engineer, 2004, Islam Masa Depan, Yogyakarta: Pustaka Pelajar. 
Bateson, Gregory and Mary Catherine Bateson. 1987. Angels Fear: Towards an Epistemology of the Sacred. New York: Bantam Books.

Dewi Fortuna Anwar., 2005. dkk (eds), Konflik Kekerasan Internal, Jakarta: Yayasan Obor Indonesia.

Diana Francis, 2006. Teori Dasar Transformasi Konflik Sosial,Yogyakarta: Penerbit Quills.

Hoda Lacey, 2003. How to Resolve Conflict in the Workplace (terj) Bern. Hidayat, Jakarta, Gramedia Pustaka Utama.

M.F. Zenrif., 2006. Realitas \& Metode Penelitian Sosial dalam Perspektif Al-Quran, Malang: UIN Malang Press.

Said, Abdul Aziz, Charles O. Lerche, Jr. and Charles O. Lerch, III. 1995. Concepts of International Politics in Global Perspective, 4th edn. Englewood Cliffs: Prentice Hall, Inc.

Said, Abdul Aziz, Nathan C. Funk and Ayse S. Kadayifci, eds. 2001. Peace and Conflict Resolution in Islam: Precept and Practice. Lanham: University Press of America.

Tarnas, Richard. 1991. The Passion of the Western Mind. New York: Ballantine Books.

Yayasan Penyelenggara Penterjemah/Penafsir Al Qur'an. 1971. Al-Qur'an dan Terjemahnya. Madinah al-Munawwasrah Mujamma al-Malik Fahdhli thiba at al Mash-haf asy Syarif. 